\title{
The Current Situation and Issues of Sexual Health Education by School Nurses in Muntinlupa City, Philippines
}

\author{
Yuko Tanaka ${ }^{1, *}$, Geraldine Ordonez Araullo $^{2}$, Maria Teresa Tuliao², Tadashi Yamashita ${ }^{3}$, \\ Kikuko Okuda ${ }^{1}$, Elizabeth C. Baua ${ }^{4}$, Hiroya Matsuo ${ }^{5}$ \\ ${ }^{1}$ Department of School Health Sciences, Faculty of Medicine, Tokushima University Graduate School, 3-18-15, kuramoto-cho, \\ Tokushima, 7708509, Japan \\ ${ }^{2}$ Department of Muntinlupa Health, Centennial Avenue, Laguerta, Tunasan, Muntinlupa City, Philippines \\ ${ }^{3}$ Kobe City College of Nursing, 3-4, gakuen-nishimachi, Nishi-ku, Kobe, 6512103, Japan \\ ${ }^{4}$ School of Nursing and Allied Health Sciences, St. Paul University Philippines, Graduate School, Philippines \\ ${ }^{5}$ Kobe University Graduate School of Health Science, 7-10-2, Tomogaoka, Suma-ku, Kobe, Japan
}

Received August 6, 2020; Revised September 27, 2020; Accepted October 19, 2020

\section{Cite This Paper in the following Citation Styles}

(a): [1] Yuko Tanaka, Geraldine Ordonez Araullo, Maria Teresa Tuliao, Tadashi Yamashita, Kikuko Okuda, Elizabeth C. Baua, Hiroya Matsuo , "The Current Situation and Issues of Sexual Health Education by School Nurses in Muntinlupa City, Philippines," Universal Journal of Public Health, Vol. 8, No. 6, pp. 185 - 192, 2020. DOI: 10.13189/ujph.2020.080601.

(b): Yuko Tanaka, Geraldine Ordonez Araullo, Maria Teresa Tuliao, Tadashi Yamashita, Kikuko Okuda, Elizabeth C. Baua, Hiroya Matsuo (2020). The Current Situation and Issues of Sexual Health Education by School Nurses in Muntinlupa City, Philippines. Universal Journal of Public Health, 8(6), 185 - 192. DOI: 10.13189/ujph.2020.080601.

Copyright $\bigcirc 2020$ by authors, all rights reserved. Authors agree that this article remains permanently open access under the terms of the Creative Commons Attribution License 4.0 International License

\begin{abstract}
Cases of sexually transmitted infections (STIs) and teenage pregnancy have been increasing among adolescents in the Philippines. School nurses (SNs) are expected to deliver quality healthcare services and provide relevant sexual health education for students. This study explores the current situation of providing sexual health education by SNs in Muntinlupa City toward health promotion and gains understanding of school health issues in the Philippines. This study employed a cross sectional research design using anonymous self-administered questionnaires, which were distributed to 23 SNs. Then, a semi-structured interview was conducted with them in Muntinlupa City. Among the 23 SNs, 30.4\% of them were affiliated to high schools. The most frequent health issues experienced by primary school students were malnutrition, gastrointestinal pain due to hunger, upper respiratory tract infection, and poor hygiene. In high schools, the most frequent health issues were poor mental health, malnutrition and early pregnancy. SNs lacked knowledge on STI, mental health, sex education, safe sex, teenage pregnancy and nutritional care for children. In conclusion,
\end{abstract}

SNs lack knowledge about sex education (early pregnancy and STIs) and mental health. Therefore, seminars should be provided for all SNs to gain adequate knowledge and skills to teach students of all types of school.

Keywords School Nurses, Sexual Health Education, Philippines

\section{Introduction}

In the Philippines, the average number of people newly diagnosed with HIV per day is 31 . The proportion of HIV positive cases in the 15-24-year-old age group increased from $25 \%$ in $2006-2010$ to $29 \%$ in 2011-2018[1]. Alternatively, it has been reported that the rate of teenage pregnancy is one in ten Filipino women aged 15-19 [2]. The low level of sexual knowledge and the risky sexual behavior of the Filipinos contribute to the increased prevalence of sexually transmitted infections (STIs) and 
teenage pregnancy [3]. Sex education by health professionals may be necessary to prevent STIs and teenage pregnancy among the younger population in the Philippines [4]. A health center in Muntinlupa City has grappled with health issues among adolescents using the Adolescent and Youth Health Program by the Department of Health in the Philippines since 2001 and has started a peer education program on HIV/AIDS and teenage pregnancy for young people in the community since 2017 $[5,6]$. While the Department of Education has started providing health education in schools using MAPEH since 2010 , students only learned about sexual behavior and STIs when they reach grade eight (13 years old) and learned about pregnancy when they reach grade 10 (15 years old) [7-9]. However, the incidence of STIs and teenage pregnancy remained still high in the Philippines [10-14]. Not only health centers and teachers but also school nurses (SNs) should play an important role in health promotion for students in the Philippines [15]. An SN is defined as a specialized health professional who promotes the well-being, academic success, and lifelong achievement of students and provides public healthcare services and health education [16]. However, there is a possibility that SNs play a crucial role in offering health education to prevent STIs and teenage pregnancy in students. Until now, the nursing practice in the school setting in promoting health for younger generations in the Philippines has not been fully explored and studied.

Therefore, this study examines the health problems frequently experienced by students and the current situation and issues regarding sexual health education by SNs in the Philippines.

\section{Materials and Methods}

\subsection{Materials}

In this study, $23 \mathrm{SNs}$ who worked at public schools (primary school and high school) and participated in conference for SNs organized by the Muntinlupa City Health Office were enrolled.

\subsection{Method}

\subsubsection{Study Design}

This was a cross sectional study conducted to identify the current situation and issues of health education by SNs in Muntinlupa City, Philippines. In addition, 30-minute semi-structured interviews in English were conducted on two groups of SNs (elementary and high school). The survey was conducted on December 4, 2018.

\subsubsection{Questionnaire}

The questionnaire contained items on the SNs' characteristics (sex, age, working experience, and affiliated school type), students' health problems, and health education. Health education was evaluated based on a 5 -point Likert-type scale: 1 , not at all; 2 , rarely; 3 , sometimes; 4 almost always; and 5, always. The Cronbach's coefficient alpha was 0.914 derived from Japanese school nurses. Its internal validity was confirmed through school nurse leaders in "A" city, education division, and Professors of school nurses program in the Philippines.

\subsubsection{Semi-structured interview}

The interview guide had two major topics: health education on the prevention of STIs and teenage pregnancy for students and the presence or absence of cooperation between the SNs and other persons in providing health education and conducting health activities.

\subsubsection{Statistical Analysis}

The collected data were analyzed using Statistical Package for the Social Sciences, ver. 23.0 (IBM Corp., Chicago, IL, USA). A chi-square test was used to determine the differences in the distribution of the baseline characteristics. Interview data were analyzed according to the health problems experienced by the students and persons who provide health education. The interviews were conducted by two health center nurses who were contributors to this study.

\subsubsection{Ethical considerations}

Participation in this study was voluntary, and the privacy and confidentiality of the participants were strictly protected. This study was conducted in cooperation with the Mayor, Muntinlupa City Health Officer, principals of each public school, and SNs in Muntinlupa City and was approved by the ethical committee of Tokushima University Hospital, Tokushima, Japan (No. 2961) and the Faculty of Nursing, St. Paul University Philippines, Tuguegarao City, Cagayan, Philippines.

\section{Results}

\subsection{Demographic Characteristics}

Table 1 shows the characteristics of the subjects. Among the 23 subjects, $19(82.6 \%)$ were women and $3(12.5 \%)$ were men. Of the $23 \mathrm{SNs}, 53.2 \%$ were less than 35 years old. With regard to working experience as a school nurse, $74 \%$ of the SNs have worked for less than 10 years. Sixteen SNs $(69.5 \%)$ were affiliated to primary schools, whereas 7 $(30.4 \%)$ worked in high schools. With regard to the number of students covered by the SNs, the average was 2,784 students (range, 613-5,700). The average number of students for whom SNs provide healthcare services was 29 per day (range, 10-70). 
Table 1. Characteristics

\begin{tabular}{|c|c|c|c|c|}
\hline & & \multicolumn{2}{|r|}{ Total } & \\
\hline & & \multicolumn{2}{|r|}{$\mathrm{N}=23$} & \\
\hline \multirow{3}{*}{ sex } & & $\mathrm{n}$ & $(\%)$ & \\
\hline & Male & 3 & $(12.5)$ & \\
\hline & Female & 19 & $(82.6)$ & \\
\hline \multirow{4}{*}{ Age } & Unknown & 1 & $(4.2)$ & \\
\hline & (1) 25 years or more and less than 30 years & 6 & $(26.1)$ & \\
\hline & (2) 30 years or more and less than 35 years & 6 & $(26.1)$ & \\
\hline & (3) 40 years or more and less than 45 years & 4 & $(17.4)$ & \\
\hline \multirow{5}{*}{ Working experiences } & (4) 45 years or more and less than 50 years & 6 & $(26.1)$ & \\
\hline & (5) 55 year and more & 1 & (4.3) & \\
\hline & (1) less than 5 years & 7 & $(30.4)$ & \\
\hline & (2) 5 years or more and less than 10 years & 10 & $(43.5)$ & \\
\hline & (3) 10 years and less than 20 years & 3 & $(13.0)$ & \\
\hline \multirow{4}{*}{ Affiliation school type } & (4) 20 year and more & 3 & $(13.0)$ & \\
\hline & (1) Primary school & 16 & $(69.6)$ & \\
\hline & i .Primary school & 12 & $(60.9)$ & \\
\hline & ii .Kinder garden and primary school & 3 & $(4.3)$ & \\
\hline \multirow{6}{*}{ Number of students in charge of a SN } & iii. K-10 & 1 & $(4.3)$ & \\
\hline & (2) High school & 7 & $(30.4)$ & \\
\hline & & Total & Primary school & High school \\
\hline & Mean & 2784 & 2850 & 2678 \\
\hline & MIN & 613 & 613 & 1643 \\
\hline & MAX & 5700 & 5700 & 3886 \\
\hline \multirow{3}{*}{ Number of students using health room per a day } & Mean & 29 & 29 & 29 \\
\hline & MIN & 10 & 10 & 10 \\
\hline & MAX & 70 & 70 & 60 \\
\hline
\end{tabular}

\subsection{Health Related Problems among Students}

Table 2 shows the health-related problems faced by primary school and high school students. In primary schools, the cumulative rate of dizziness, headache, abdominal pain, and stomachache was $62.5 \%$. The rates of malnutrition, wound, poor hygiene, toothache, immunization/deworming, and upper respiratory tract infection/fever were $31.3 \%, 18.8 \%, 18.8 \%, 12.5 \%, 12.5 \%$, $12.5 \%$, and $12.5 \%$, respectively. However, in high schools, the rates of mental health, malnutrition, poor hygiene, early pregnancy, poor lifestyle, and common ailments were $57.1 \%, 42.9 \%, 14.3 \%, 14.3 \%, 14.3 \%$, and $14.3 \%$, respectively.

\subsection{Health Education by SNs}

Table 3 shows the items and frequency for health education programs provided by the SNs. In primary schools, education regarding proper nutrition and infectious diseases was always provided to students. Health education lessons regarding hand washing, immunization, dental health, visual health, tobacco and alcohol use, excise/physical activities, and drug use were almost always taught to students, while lessons on menstruation and puberty were sometimes taught in primary schools. However, education regarding mental health, sex, family abuse, dating, STIs, pregnancy, and marriage was not provided for students by SNs in all schools.

Alternatively, in high schools, all health education lessons were taught to students. Lessons on hand washing, proper nutrition, immunization, infectious disease, and drug use were always taught to students. Furthermore, education on STIs, mental health, and tobacco and alcohol use was almost always provided for students. Lessons on pregnancy and family abuse were sometimes taught, while education on sex, dating, and marriage was rarely provided for students. Significant differences in marriage between primary and high schools $(p<0.05)$ were observed. In addition, differences in STIs and pregnancy were noted between primary and high schools $(\mathrm{p}=0.055$ and $\mathrm{p}=0.089$, respectively). 
Table 2. Health related problems among students in schools (plural answer)

\begin{tabular}{|c|c|c|c|c|c|c|c|c|c|}
\hline \multirow[b]{2}{*}{ No. } & \multirow[b]{2}{*}{ Health issues } & \multicolumn{2}{|c|}{$\begin{array}{c}\text { Total } \\
(\mathrm{N}=23)\end{array}$} & \multirow[b]{2}{*}{ Health issues } & \multicolumn{2}{|c|}{$\begin{array}{l}\text { Primary school } \\
(\mathrm{n}=16)\end{array}$} & \multirow[b]{2}{*}{ Health issues } & \multicolumn{2}{|c|}{$\begin{array}{l}\text { High school } \\
(\mathrm{n}=7)\end{array}$} \\
\hline & & $\mathrm{n}$ & $(\%)$ & & $\mathrm{n}$ & $(\%)$ & & $\mathrm{n}$ & $(\%)$ \\
\hline 1 & $\begin{array}{l}\text { *Dizziness, head ache, } \\
\text { abdominal pain, } \\
\text { stomachache }\end{array}$ & 10 & $(43.5)$ & $\begin{array}{l}\text { *Dizziness, head ache, } \\
\text { abdominal pain, } \\
\text { stomach ache }\end{array}$ & 10 & $(62.5)$ & Mental health & 4 & $(57.1)$ \\
\hline 2 & Nutrition/Malnutrition & 8 & $(34.8)$ & Nutrition/Malnutrition & 5 & $(31.3)$ & Nutrition/ Malnutrition & 3 & $(42.9)$ \\
\hline 3 & Mental health & 4 & $(17.4)$ & Wound & 3 & $(18.8)$ & $\begin{array}{l}\text { Hygiene/poor personal } \\
\text { hygiene }\end{array}$ & 1 & (14.3) \\
\hline 4 & $\begin{array}{l}\text { Hygiene/poor personal } \\
\text { hygiene }\end{array}$ & 3 & $(13.0)$ & $\begin{array}{l}\text { Hygiene/poor personal } \\
\text { hygiene }\end{array}$ & 2 & $(12.5)$ & Early pregnancy & 1 & $(14.3)$ \\
\hline 5 & Wound & 3 & (13.0) & Toothache & 2 & $(12.5)$ & Healthy life style & 1 & (14.3) \\
\hline 6 & $\begin{array}{l}\text { Decreasing number of } \\
\text { students participating in } \\
\text { immunization \& } \\
\text { deworming }\end{array}$ & 2 & $(8.7)$ & $\begin{array}{l}\text { Decreasing number of } \\
\text { students participating in } \\
\text { immunization \& deworming }\end{array}$ & 2 & $(12.5)$ & Common ailments & 1 & $(14.3)$ \\
\hline 7 & Toothache & 2 & $(8.7)$ & $\begin{array}{l}\text { Upper respiratory tract } \\
\text { infection, Fever }\end{array}$ & 2 & $(12.5)$ & - & - & \\
\hline 8 & $\begin{array}{l}\text { Upper respiratory tract } \\
\text { infection, Fever }\end{array}$ & 2 & $(8.7)$ & bullying & 1 & $(6.3)$ & - & - & \\
\hline 9 & Common ailments & 2 & $(8.7)$ & Healthy life style & 1 & $(6.3)$ & - & - & \\
\hline 10 & Healthy life style & 2 & $(8.7)$ & Common ailments & 1 & $(6.3)$ & - & - & \\
\hline 11 & Early pregnancy & 1 & $(4.3)$ & - & - & & - & - & \\
\hline 12 & Bullying & 1 & $(4.3)$ & - & - & & - & - & \\
\hline
\end{tabular}

*Children go to school not eating breakfast, so one 8 are headache, stomachache and dizziness

Table 3. Comparison between Primary school and High school on Health Education (items and frequency)

\begin{tabular}{|c|c|c|c|c|c|c|c|c|}
\hline & \multicolumn{3}{|c|}{$\begin{array}{c}\text { Primary school } \\
n=16\end{array}$} & \multirow{2}{*}{$\begin{array}{l}\text { Primary } \\
\text { vs High } \\
\text { school } \\
\text { p }\end{array}$} & & \multicolumn{3}{|c|}{$\begin{array}{c}\text { High school } \\
n=7\end{array}$} \\
\hline & $\mathrm{n}$ & $(\%)$ & Mean \pm SD & & & $\mathrm{n}$ & $(\%)$ & $\begin{array}{l}\text { Mean } \pm S \\
\text { D }\end{array}$ \\
\hline Proper nutrition & 16 & $(100.0)$ & 5.0 & 0.118 & Hand washing & 7 & $(100.0)$ & $4.9 \pm 0.4$ \\
\hline $\begin{array}{l}\text { Infectious Diseases ( Dengue, } \\
\text { Zika, etc) }\end{array}$ & 16 & $(100.0)$ & 5.0 & 0.278 & Proper nutrition & 7 & $(100.0)$ & $4.6 \pm 0.5$ \\
\hline Hand washing & 16 & $(100.0)$ & $4.9 \pm 0.3$ & 0.769 & Immunizations & 7 & $(100.0)$ & $4.6 \pm 0.5$ \\
\hline Immunizations & 16 & $(100.0)$ & $4.8 \pm 0.6$ & 0.579 & $\begin{array}{l}\text { Infectious Diseases ( Dengue, } \\
\text { Zika, etc) }\end{array}$ & 7 & $(100.0)$ & $4.6 \pm 0.5$ \\
\hline Dental Health & 16 & $(100.0)$ & $4.7 \pm 0.7$ & 0.189 & Drugs & 7 & $(100.0)$ & $4.6 \pm 0.5$ \\
\hline Visual Health & 16 & $(100.0)$ & $4.7 \pm 0.5$ & 0.135 & Sexually Transmitted Infections & 7 & $(100.0)$ & $4.4 \pm 1.0$ \\
\hline Tobacco \& alcohol use & 16 & $(100.0)$ & $4.5 \pm 0.9$ & 0.671 & Mental Health & 7 & $(100.0)$ & $4.4 \pm 0.8$ \\
\hline Exercise/physical activities & 16 & $(100.0)$ & $4.5 \pm 0.8$ & 0.671 & Tobacco \& alcohol use & 7 & $(100.0)$ & $4.4 \pm 0.5$ \\
\hline Drugs & 16 & $(100.0)$ & $4.4 \pm 0.7$ & 0.492 & Exercise/physical activities & 7 & $(100.0)$ & $4.4 \pm 0.5$ \\
\hline Menstruation & 16 & $(100.0)$ & $3.9 \pm 0.5$ & 0.431 & Dental Health & 7 & $(100.0)$ & $4.3 \pm 0.7$ \\
\hline Puberty & 16 & $(100.0)$ & $3.8 \pm 0.6$ & 0.922 & Visual Health & 7 & $(100.0)$ & $4.3 \pm 0.5$ \\
\hline Mental Health & 15 & $(93.8)$ & $3.5 \pm 1.2$ & 0.103 & Puberty & 7 & $(100.0)$ & $4.1 \pm 0.7$ \\
\hline Sex Education & 15 & $(93.8)$ & $3.0 \pm 1.1$ & 0.222 & Menstruation & 7 & $(100.0)$ & $4.1 \pm 0.4$ \\
\hline Family abuse & 14 & $(87.5)$ & $3.0 \pm 1.2$ & 0.135 & Pregnancy & 7 & $(100.0)$ & $4.0 \pm 0.8$ \\
\hline Dating & 13 & (81.3) & $2.7 \pm 1.2$ & 0.118 & Family abuse & 7 & $(100.0)$ & $4.0 \pm 0.8$ \\
\hline $\begin{array}{l}\text { Sexually Transmitted } \\
\text { Infections }\end{array}$ & 12 & $(75.0)$ & $3.1 \pm 1.5$ & 0.055 & Sex Education & 7 & $(100.0)$ & $3.9 \pm 0.9$ \\
\hline Pregnancy & 11 & $(68.8)$ & $2.7 \pm 1.4$ & 0.089 & Dating & 7 & $(100.0)$ & $3.4 \pm 0.5$ \\
\hline Marriage & 10 & $(62.5)$ & $2.1 \pm 1.0$ & $*$ & Marriage & 7 & $(100.0)$ & $3.3 \pm 0.8$ \\
\hline
\end{tabular}

Table 4. Methods of Health Education by School Nurses

\begin{tabular}{|c|c|c|c|c|c|c|c|}
\hline & & \multirow{2}{*}{\multicolumn{2}{|c|}{$\begin{array}{l}\text { Total } \\
(\mathrm{N}=23)\end{array}$}} & \multirow{2}{*}{\multicolumn{2}{|c|}{$\begin{array}{c}\text { Primary school } \\
(\mathrm{n}=16)\end{array}$}} & \multirow{2}{*}{\multicolumn{2}{|c|}{$\begin{array}{c}\text { High school } \\
(\mathrm{n}=7)\end{array}$}} \\
\hline & & & & & & & \\
\hline & & $\mathrm{n}$ & $(\%)$ & $\mathrm{n}$ & $(\%)$ & $\mathrm{n}$ & $(\%)$ \\
\hline (1) Participation and cooperation with teachers on Health Education & (Yes) & 22 & $(95.7)$ & 15 & $(93.8)$ & 7 & $(100)$ \\
\hline (2) Do you have class of Health Education? & (Yes) & 22 & $(95.7)$ & 15 & $(93.8)$ & 7 & $(100)$ \\
\hline (3) School Nurse educate students by only one. & (Yes) & 17 & $(73.9)$ & 10 & $(62.5)$ & 7 & $(100)$ \\
\hline
\end{tabular}


Table 5. Health education issues which School Nurses seek to provide (plural answer)

\begin{tabular}{|c|c|c|c|c|c|c|c|c|c|}
\hline \multirow[b]{2}{*}{ No } & \multirow[b]{2}{*}{ item } & \multicolumn{2}{|c|}{$\begin{array}{c}\text { Total } \\
(\mathrm{N}=23)\end{array}$} & \multirow[b]{2}{*}{ item } & \multicolumn{2}{|c|}{$\begin{array}{c}\text { Primary } \\
\text { school } \\
(\mathrm{n}=16)\end{array}$} & \multirow[b]{2}{*}{ item } & \multicolumn{2}{|c|}{$\begin{array}{c}\text { High school } \\
\quad(\mathrm{n}=7)\end{array}$} \\
\hline & & $\mathrm{n}$ & $(\%)$ & & $\mathrm{n}$ & $(\%)$ & & $\mathrm{n}$ & $(\%)$ \\
\hline 1 & $\begin{array}{l}\text { Mental Health } \\
\text { (Depression, Stress) }\end{array}$ & 12 & $(52.2)$ & STIs/HIV & 6 & $(37.5)$ & $\begin{array}{l}\text { Mental Health } \\
\text { (Depression, Stress) }\end{array}$ & 7 & $(100)$ \\
\hline 2 & STIs/HIV & 7 & (30.4) & Mental Health & 5 & $(31.3)$ & $\begin{array}{l}\text { Safe sex / Teenage } \\
\text { pregnancy }\end{array}$ & 2 & (28.6) \\
\hline 3 & $\begin{array}{l}\text { Adolescents } \\
\text { Reproductive health }\end{array}$ & 3 & $(13.0)$ & $\begin{array}{l}\text { Adolescents } \\
\text { Reproductive health }\end{array}$ & 3 & $(18.8)$ & STIs/HIV & 1 & (14.3) \\
\hline 4 & $\begin{array}{l}\text { Teenage } \\
\text { Pregnancy/Safe sex }\end{array}$ & 3 & $(13.0)$ & Teenage Pregnancy & 1 & $(6.3)$ & & & \\
\hline 5 & $\begin{array}{l}\text { Food care of Child } \\
\text { for parents }\end{array}$ & 1 & $(4.3)$ & $\begin{array}{l}\text { Food care of Child for } \\
\text { parents }\end{array}$ & 1 & $(6.3)$ & & & \\
\hline 6 & Counseling & 1 & $(4.3)$ & Counseling & 1 & $(6.3)$ & & & \\
\hline
\end{tabular}

\subsection{Methods of Health Education by SNs}

Table 4 shows the methods of health education used by SNs. In primary schools, $93.8 \%$ of the SNs provided health education for the teachers. However, $62.5 \%$ of the SNs provided health education for students by themselves. In high school, SNs provided health education for teachers; they have health education classes, and they educated students one by one.

\subsection{Health Education Issues That School Nurse Seek to Solve}

Table 5 shows the health education issues that SNs seek to solve. SNs in primary schools sought to provide knowledge about STIs/HIV (37.5\%), mental health $(31.3 \%)$, adolescent reproductive health $(18.8 \%)$, teenage pregnancy, child food care for parents and counseling (6.3\%). All SNs in high schools sought to provide knowledge about mental health (depression and stress) $(100 \%)$, safe sex/teenage pregnancy $(28.6 \%)$, and STIs/HIV (14.3\%).

\subsection{SNs' Perception of Health Education on the Prevention of STIs and Teenage Pregnancy}

Table 6 shows the SNs' perception of the problems in providing health education on the prevention of STIs and teenage pregnancy. In primary schools, "poverty," "lack of parental cooperation," "lack of budget," "lack of materials (handouts)," "time constraints," "lack of training/seminars," and "lack of support from staff/manpower" were the problems perceived by the SNs in providing health education. However, in high schools, "poor nutrition," "lack of cooperation from the students and their parents," "lack of budget," and "time constraints" were the problems perceived by the SNs. SNs had health education and activities with method, followings. They were health teachers, guidance teachers, guidance counselors, feeding coordinators, and teaching personnel not only in schools but also in private health offices, non-governmental organizations, and the World Health Organization (WHO).

\section{Discussion}

School nurses (SNs) in Muntinlupa City, the Philippines, have been providing public health education for students along with their dependent on a variety of health problems caused by poverty, based on their developmental age. However, sexual education such as prevention of teenage pregnancy and sexually transmitted infections (STIs) was not adequately provided.

Students in public schools face various health problems due to poverty such as malnutrition, developmental disorders, poor mental health, and injury. In particular, students' tendency to miss meals due to poverty during elementary and high school education was deemed as the primary cause of nutritional deficiencies, such as anemia and Vitamin A deficiency, which lead to poor mental health including anxiety [17,18]. In high school, in addition to poor mental health including depression, students face problems related to sexuality, such as teenage pregnancy. The Department of Health of the Philippines reported that malnutrition, teenage pregnancy, STIs, smoking, alcohol dependency, drug abuse, risky sexual behavior, and violence including victimization through sex crimes were prevalent health problems during childhood and adolescence. Students in Muntinlupa City are no exception [19]. UNICEF is raising the alarm that victimization through sex crimes is a barrier to the physical and mental development of children in the Philippines [20]. 
Table 6. School Nurses' perception on the problems in health for STIs and teenage pregnancy prevention

\begin{tabular}{|c|c|c|}
\hline \multirow{14}{*}{$\begin{array}{r}\text { Primary } \\
\text { School }\end{array}$} & Poverty & $\begin{array}{l}\text { Poverty is a major factor for our children. Sometimes they might be understood or unhygienic } \\
\text { it is because of poverty affecting their lifestyle. }\end{array}$ \\
\hline & \multirow{5}{*}{$\begin{array}{l}\text { Lack of Cooperation with the } \\
\text { parents }\end{array}$} & Obtaining parent's consent \\
\hline & & Lack of parents/guardians \\
\hline & & Deworming-participation of parents \\
\hline & & parents cooperation on some program of the school \\
\hline & & Cooperation with the parents and budget for the materials \\
\hline & Lack of budget & $\begin{array}{l}\text { Lack of time and budget, Teachers should also be trained for some programs related to health } \\
\text { especially for children. }\end{array}$ \\
\hline & Lack of materials( handouts) & Lack of materials( handouts) \\
\hline & \multirow{3}{*}{ Time constraints } & $\begin{array}{l}\text { With so many health programs to be implemented, it is hard to find adolescent and quality } \\
\text { time to provide for each program. }\end{array}$ \\
\hline & & School focuses and resources like hand washing focuses \\
\hline & & Unfinish workload \\
\hline & \multirow[b]{2}{*}{ Lack of training /Seminar } & Time constraints, lack of trainning/seminor, lack of manpower \\
\hline & & $\begin{array}{l}\text { Some of the programs that implemented by DOTT/WHO cannot be easily implemented in } \\
\text { my school because of lack of proper training like adolescent reproductive health. }\end{array}$ \\
\hline & $\begin{array}{l}\text { Lack of support staff, } \\
\text { manpower }\end{array}$ & Lack of support staff for implementation of school promotion activities \\
\hline \multirow{7}{*}{$\begin{array}{l}\text { High } \\
\text { School }\end{array}$} & Poor nutrition & Poor nutrition \\
\hline & \multirow{3}{*}{$\begin{array}{l}\text { Lack of Cooperation with } \\
\text { students and the parents }\end{array}$} & $\begin{array}{l}\text { Students \& Parents noncompliance to school attendance is one of the challenges in my } \\
\text { school. }\end{array}$ \\
\hline & & Cooperation with students and the parents \\
\hline & & $\begin{array}{l}\text { Refusal of parents to sign permits for deworming \& immunization, over apping or over } \\
\text { loading of activities }\end{array}$ \\
\hline & \multirow{2}{*}{ Lack of budget } & Budget for the implementation of the health programs. \\
\hline & & Lack of support especialy financial \\
\hline & Time constraint & Time constraint, SN took pregnant students to clinic. \\
\hline
\end{tabular}

Thus, SNs are expected to be equipped to promptly address various public health problems, including mental health and sexuality-related problems that students are facing [21]. In the Philippines, the present situation of health education by $\mathrm{SNs}$ is as follows. One $\mathrm{SN}$ has responsibility to a large number of students. The maximum number of enrolled students in elementary and high schools are 5,700 and 3,886, respectively, whereas the number of students that visit healthcare rooms is 70 and 60 , respectively. SNs provide health education centered on public health such as appropriate nutritional guidance, hand washing instructions, prevention of infectious diseases, and vaccination. All SNs in high schools provide sex education; however, such information in elementary schools is lacking.

Why do SNs in elementary schools fail to provide sufficient sex education including prevention of teenage pregnancy and STIs? Lack of knowledge is a possible reason. Several SNs lack awareness of the increase in teenage pregnancy and STIs and their effect on health, whereas other SNs lack knowledge on the symptoms, treatment, and prevention of STIs. One possible reason is that SNs lack the opportunity to attend seminars, from which they can gain new expertise, due to the excessive workload in schools [22]. The department of education also had no plans for sexual education to prevent teenage pregnancy and STIs for SNs.

Second, the cultural context renders the promotion of sex education difficult [23]. In the Philippines, sex-related issues are regarded as taboo for religious reasons [24], which led to the inadequate promotion of sex education. The Philippines is predominantly Catholic, where premarital sex, contraception, and abortion are prohibited in society. Myths and misperceptions as regards sex and sexuality might be widespread among adolescents, which has a negative impact on their service-seeking behavior [25].

Thus, obtaining the understanding and cooperation of parents to collaborate with teachers in terms of sex education in schools is difficult. Lastly, a lack of collaboration between SNs and teachers and experts is observed. For the prevention of teenage pregnancy and STIs, collaboration is required not only with teachers but also with health centers and hospitals. However, only a few SNs have such a collaboration. These points are considered the main factors for the inadequate sex education provided to students. Some schools are afraid that sexual education may lead to earlier sexual initiation and risky sexual activity among less-informed young adults [26]. Therefore, SNs had offer health education to students in several ways to compensate for the lack of sexual health knowledge and time constraints. SNs must provide health education for health teachers, guidance teachers, guidance counselors, feeding coordinators, and teaching personnel not only in schools but also in private health offices, non-governmental organizations, and the 
World Health Organization (WHO).

Therefore, although the SNs' role is public health nursing in schools, they are also expected to be health educators and coordinators to promote sexual health education.

What form of support, then, is necessary for the promotion of sex education via SNs? First, the education division and health division should pool resources and hold seminars to enable SNs to gain new expertise and improve their ability to carry out instruction and education. Second, researchers and health centers should provide support for the creation of a cooperative environment between SNs and health experts. Finally, in college courses for pre-service SNs, the contents of the curriculum should include strategies for mental health and sex education, which are necessary for the promotion of the mental and physical health of students.

Limitations of the Study:

The sample size is small, and the Questionnaires' reliability could not be confirmed. It is recognized that conducting reliability tests on the questionnaire is needed against a larger sample to confirm its reliability for SNs in the Philippines.

\section{Conclusion}

Many students with various health problems require the health services provided by SNs. However, the current scenario of sex education in the Philippines is insufficient to mitigate the increase in teenage pregnancy and STIs among students. There was socio-cultural barrier for adolescents to access sexual information in the Philippines. Addressing this issue would require SNs to play an important role not only in public health nursing but also in school health nursing as health educators. SNs should be empowered through competency in sexual health education. Therefore, city health centers should collaborate with the City Education Division to set up an environment conducive for sex and health education for all SNs in which to gain knowledge and teaching skills.

\section{Acknowledgements}

We would like to thank all school nurses, the Mayor of Muntinlupa city, Dr. Maria Teresa Reyes Tuliao of the City Health Office, Dr. Geraldine Ordonez of the City Health Center, and the City Education Division, College of Nursing, University of the Philippines.

\section{REFERENCES}

[1] HIV/AIDS and ART Registry of the Philippines,
Department of Health in the Philippines. Online available from http://www.doh.bov.ph/sites/files/statistics/EB_HIV_MarAIDSreg 2018.

[2] Philippines STATISTICS Authority: One in Ten Young Filipino Women Age 15 to 19 Is Already A Mother or Pregnant with First Child (Final Results from the 2013 National Demographic and Health Survey), Republic of the Philippines, 2014. Online available from https://psa.gov.ph/ sites/default/files/attachments/hsd/pressrelease/Table\%201. \%20Early\%20pregnancy\%20and\%20motherhood.pdf.

[3] WHO (1995-2003): Sexual and Reproductive Health of Adolescents and Youths in the PHILIPPINES. Online available from http://www.wpro.who.int/publications/docs/ ASRHphilippines.pdf.

[4] National Policy and Strategic Framework on Adolescent Health and Development, Office of Department of Health, Republic of the Philippines, 2013. Online available from https://www.doh.gov.ph/Adolescent-Health-and Development-Program.

[5] Y. Tanaka, C.L.Lave, T. Yamashita, H.Matsuo, The Current Situation of knowledge, behavior and attitude related to STIs prevention among high school students in the Philippines, Bulletin of Health Sciences Kobe, 31, 1-13, 2016.

[6] Peer Education Training Manual on Adolescent Sexuality and Reproductive Health and Teen Pregnancy Prevention, Department of Health in the Philippines, 2017. Online available from https://www.doh.gov.ph/sites/default/files/p ublications/Peer-Education-Training-Manual.pdf.

[7] DM 193, s. 2010 - Training Of First Year Teachers Of Technology And Livelihood Education (Tle), Music And Arts, Physical Education And Health (Mapeh) And Edukasyon Sa Pagpapahalaga (Ep) On The 2010 Secondary Education Curriculum (Sec). Department of education in the Philippines, April 29, 2010. Online available from http://www.deped.gov.ph/sites/default/files/memo/2010/D M_s2010_193.pdf.

[8] World Data on Education, International Bureal of Education. 7th edition, 2010/11. Online available from http://www.ibe. unesco.org/sites/default/files/Philippines.pdf.

[9] Sex education enters school curriculum, Department of Education, Philippines AIDS Council-Department of Education (DepEd). Online available from http://www.pnac .org.ph/index.php?mact=News, cntnt01,

[10] Philippine Statistics Authority (PSA). National Demographic and Health Survey 2017. Online available from

https://psa.gov.ph/sites/default/files/PHILIPPINE\%20NATI ONAL\%20DEMOGRAPHIC\%20AND\%20HEALTH\%20 SURVEY\%202017_new.pdf

[11] World Bank Group. Adolescent fertility rate (births per 1,000 women ages 15-19). Online available from https://data.worldbank.org/indicator/SP.ADO.TFRT. 2019

[12] POPCOM. "POPCOM calls for prevention of repeat teenage pregnancy". The Philippine Information Agency news. Online available from https://pia.gov.ph/news/articles/1029 554. 1 November 2019. 
[13] Y. Tanaka, C. L. Llave, M.T. Reyes Tuliao, T. Yamashita, H. Matsuo, Knowledge, Behavior and Attitudes Concerning STI Prevention among Out-of-School Youth in the Philippines. Universal Journal of Public Health, Vol. 5, No.3, 127-134, 2017.

[14] M. Gunchi, Y. Tanaka, M.T. R. Tuliao, G. Ordonez, E. Hapsari, H. Matsuo. Current Status of Knowledge and Attitude toward STI Prevention among Out-of-school Youth in the Philippines, Universal Journal of Public Health, Vol.6, No.6, 359-365, 2018.

[15] Public Health Nursing in the Philippines, National League of Government Nurses, 10th/ed, 2007.

[16] A.S. Maglaya. Nursing Practice in the Community fifth edition, Argonauta Corporation, 2009.

[17] Iron Deficiency Anemia, Philippines Health Advisory, Public Health Resources, 2017. Online available from https://publichealthresources.blogspot.com/2017/10/iron-de ficiency-anemia-philippine.html.

[18] P. Detzel, S. Wieser. Food Fortification for Addressing Iron Deficiency in Filipino Children: Benefits and Cost-Effectiveness, Annals of Nutrition and Metabolism, Vol.66, No.2, 35-42, 2017. Online available from https://www.karger.com/article/FullText/375144.

[19] ADOLESCENT HEALTH AND DEVELOPMENT PROGRAM, Department of Health in the Philippines. Online available from https://www.doh.gov.ph/AdolescentHealth-and-Development-Program.

[20] UNICEF, National Baseline Study on Violence against Children: Philippines, EXECUTIVE SUMMARY, October 2016. Online available form https://www.unicef.org/philipp ines/media/491/file.

[21] WHO, Adolescent Health and Development Program MANUAL OF OPERATIONS, With technical support from World Health Organization - Philippines Country Office (WHO-PHL). Online available from https://www.doh.gov.p h/sites/default/files/publications/WHO_DOH_2017_12082 017 full.pdf.

[22] K. M. L. Macairan, R. M. F Oducado, M. E Minsalan, R. G. Recodo, G. F. D. Abellar. Quality of Work Life of Public School Nurses in the Philippines, Nurse Media Journal of Nursing, 9, 1-2, 2019.

[23] Sex education debate heats up in Philippines. CDC National Prevention Information Network, June 22, 2010. Online available from https://www.thebody.com/article/burma-hivrise-among-men-sex-men.

[24] R.V.Baring. REPRODUCTIVE HEALTH BILL IN THE PHILIPPINES: Sources of Conflict between the Church and its Proponents, Social Development Research Center, De La Salle University, SDRC Occasional Paper Series No. 1, 2012.

[25] UNICEF Philippines, Situation Analysis of Children in the Philippines, Coram International at Coram Children's Legal Centre (CCLC) 2018. Online available from https://www.u nicef.org/philippines/media/976/file/Situation\%20Analysis $\% 20$ of $\% 20$ Children $\% 20$ in $\% 20$ the $\% 20$ Philippines $\% 20-\% 20$ Full\%20Report\%20(unedited).pdf

[26] Philippine Institute for Development Studies, Unintended Consequences: The Folly of Uncritical Thinking, Page 5, 2017. Online available from: https://pidswebs.pids.gov.ph/ CDN/PUBLICATIONS/pidsbk2017-unintended_fnl.pdf [29.06.17]617 NDHS 2013, p.87. 